\title{
Late winter primary production and bacterial production in sea ice and seawater west of the Antarctic Peninsula
}

\author{
Steven T. Kottmeier \& Cornelius W. Sullivan \\ Marine Biology Research Section, Department of Biological Sciences, University of Southern California, Los Angeles, \\ California 90089-0371, USA
}

\begin{abstract}
The Southern Ocean is believed to be unproductive during winter due principally to low irradiance. On the 1985 Wintercruise of the R/V Polar Duke, considerable microbial biomass and rates of primary production and bacterial production were found in sea ice up to $1.79 \mathrm{~m}$ thick. Microbial activity associated with sea ice was equal to that found in several meters of underlying seawater. Downwelling irradiance was adequate for net production near the surface of ice-free water and in sea ice. Approximately $40 \%$ of the newly fixed carbon incorporated by ice microalgae was assimilated into protein, suggesting that net growth was taking place without nutrient limitation. We propose that annual estimates of primary production should be revised upward by as much as $25 \%$ to account for this unexpected productivity during late winter in the Southern Ocean. In addition, sea ice should be viewed as a concentrated source of microalgal carbon for grazers such as krill during late winter when phytoplankton in the water column are scarce. In situ observations by divers suggest that sea ice may also serve as an important nursery ground for larval krill during this time of year. We conclude that both the quantity of sea ice associated production and seasonal timing of this production are important factors in Antarctic trophodynamics.
\end{abstract}

\section{INTRODUCTION}

Research cruises conducted from austral spring to autumn have found high standing crops of phytoplankton in the inshore waters of Antarctica (El-Sayed \& Turner 1977). Patchy blooms of diatoms, dinoflagellates, flagellates, and Phaeocystis spp. have been reported in excess of $25 \mathrm{mg} \mathrm{Chl} \mathrm{a} \mathrm{m}^{-3}$ in coastal waters west of the Antarctic Peninsula (Mandelli \& Burkholder 1966, El-Sayed 1967, von Bodungen et al. 1982, ElSayed 1984). Primary productivity in these regional blooms is well correlated with high biomass, reaching up to $3.6 \mathrm{~g} \mathrm{C} \mathrm{m}^{-2} \mathrm{~d}^{-1}$ with peaks at depths corresponding to 25 to $50 \%$ of surface irradiance (El-Sayed 1984). In addition, the marginal ice-edge zone has been reported to be a region of increased phytoplankton biomass and primary productivity (Hart 1934, El-Sayed 1971, El-Sayed \& Taguchi 1981, Nelson \& Gordon 1982, Smith \& Nelson 1985, 1986). Such temporally and spatially episodic primary production apparently supports the krill-dominated food webs of the Southern Ocean during much of the year.
Research in the Weddell Sea (Ackley et al. 1979, Garrison \& Buck 1982, 1986, Garrison et al. 1983, Clark \& Ackley 1984), and at several coastal sites (Bunt 1963, Whitaker 1977, Hoshiai 1977, 1981, McConnville \& Wetherbee 1983, Palmisano \& Sullivan 1983, McConnville et al. 1985, Sullivan et al. 1985, Grossi et al. 1987) suggests that significant primary production is also associated with sea ice (pack ice and land-fast ice). Ice provides several microhabitats for blooms of microalgae (Whitaker 1977, Garrison et al. 1986) and supports a microbial loop analogous to that found in the underlying seawater (Sullivan \& Palmisano 1984, Kottmeier et al. 1987). Blooms of ice microalgae have been observed to have standing crops of $300 \mathrm{mg} \mathrm{Chl} \mathrm{a}$ $\mathrm{m}^{-2}$ (Palmisano \& Sullivan 1983) and estimates of primary production have been reported to be as high as $2 \mathrm{~g} \mathrm{C} \mathrm{m}^{-2} \mathrm{~d}^{-1}$ (Grossi et al. 1987).

Scant information is available however on primary production in the Southern Ocean during winter; no information is available on bacterial production. Significant chlorophyll $a$ and net production were found from September to October 1978 in the Scotia Sea by 
El-Sayed \& Weber (1982). At the highest southern latitude where sea ice exists (McMurdo Sound, $77^{\circ}$ $51^{\prime}$ S) we have measured standing crops of microalgae

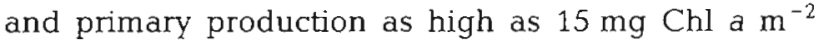
and $58 \mathrm{mg} \mathrm{C} \mathrm{m}^{-2} \mathrm{~d}^{-1}$ respectively for the transition from winter to spring (Sep-Oct) in sea ice; negligible phytoplankton biomass and production were found in the underlying seawater (Kottmeier \& Sullivan unpubl. obs.). Several factors affecting quantity and quality of light (day length, low sun angle, increased reflectance, spectral composition, ice cover, cloud cover, and stormy conditions) have been hypothesized to limit photosynthesis from spring to autumn (El-Sayed 1971, Holm-Hansen et al. 1977, El-Sayed 1978, 1984, Jacques 1983, Heywood \& Whitaker 1984, Palmisano et al. 1987). As a result winter has been regarded as a long 'polar night' (Heywood \& Whitaker 1984) and period of no primary production even in recent estimates of annual production (Smith \& Nelson 1986). The 1985 Wintercruise of the $\mathrm{R} / \mathrm{V}$ Polar Duke thus provided an ideal opportunity to make a preliminary study of primary production and bacterial production in the water column and sea ice during late winter, the time of maximal sea ice coverage in the Southern Ocean.

\section{MATERIALS AND METHODS}

Ten stations were taken from 26 August to 17 September 1985 in the region of the southern Bransfield Strait to northern Marguerite Bay along the western Antarctic Peninsula. Downwelling irradiance was measured by a spherical irradiance meter (Model QSP-
200, Biospherical Instruments) and surface irradiance by a hemispherical irradiance meter (Model QSR-240, Biospherical Instruments), mounted on the helicopter deck, connected through a digital scalar irradiance meter (Model QSP-170A, Biospherical Instruments). Samples of seawater were taken with $10 \mathrm{l}$ Niskin bottles (General Oceanic) from 100, 10, 1, and $0.1 \%$ light depths at hydrostations and at $3 \mathrm{~m}$ at ice stations. At sea ice stations, ice coverage ranged from $5 / 10$ to $10 / 10$, thickness varied from 0.20 to $1.79 \mathrm{~m}$, and measured less than $20 \mathrm{~m}$ in the longest dimension horizontally (Table 1). Such ice is classified as young to thick, first-year, 'cake' ice (Stringer et al. 1984). At 6 stations entire cores of ice were taken using a CRREL auger $(7.6 \mathrm{~cm}$ dia). Ice cores were cut horizontally into $20 \mathrm{~cm}$ sections in the field as described elsewhere (Grossi \& Sullivan 1985). Additional bottom sections of ice were taken at each sea ice station, gently sawed and scraped into large volumes of $0^{\circ} \mathrm{C}, 0.2 \mu \mathrm{m}$ Nuclepore-filtered seawater (FSW), and allowed to melt at $0^{\circ} \mathrm{C}$ as described previously (Palmisano et al. 1985). This procedure permitted release of sea ice microbial communities from the ice matrix and reduced the risk of osmotic shock from low salinity meltwater. Within $6 \mathrm{~h}$ of collection, the resulting slurry of ice meltwater was used in experiments designed to measure rates of primary and bacterial production. Downwelling irradiance beneath cakes of sea ice was measured by scuba divers holding a spherical irradiance meter (Model QSI-140, Biospherical Instruments). Location of stations, date of sampling, depth of water samples, and thickness of ice cores are presented in Table 1 and Fig. 1.

Measurements of primary production were carried out in $300 \mathrm{ml}$ BOD bottles (Wheaton) using either

Table 1. Station numbers, type, dates, location, water depths, depths of $1 \%$ and $0.1 \%$ of surface irradiance, thickness of sea ice, and ice coverage for 1985 Wintercruise of R/V Polar Duke

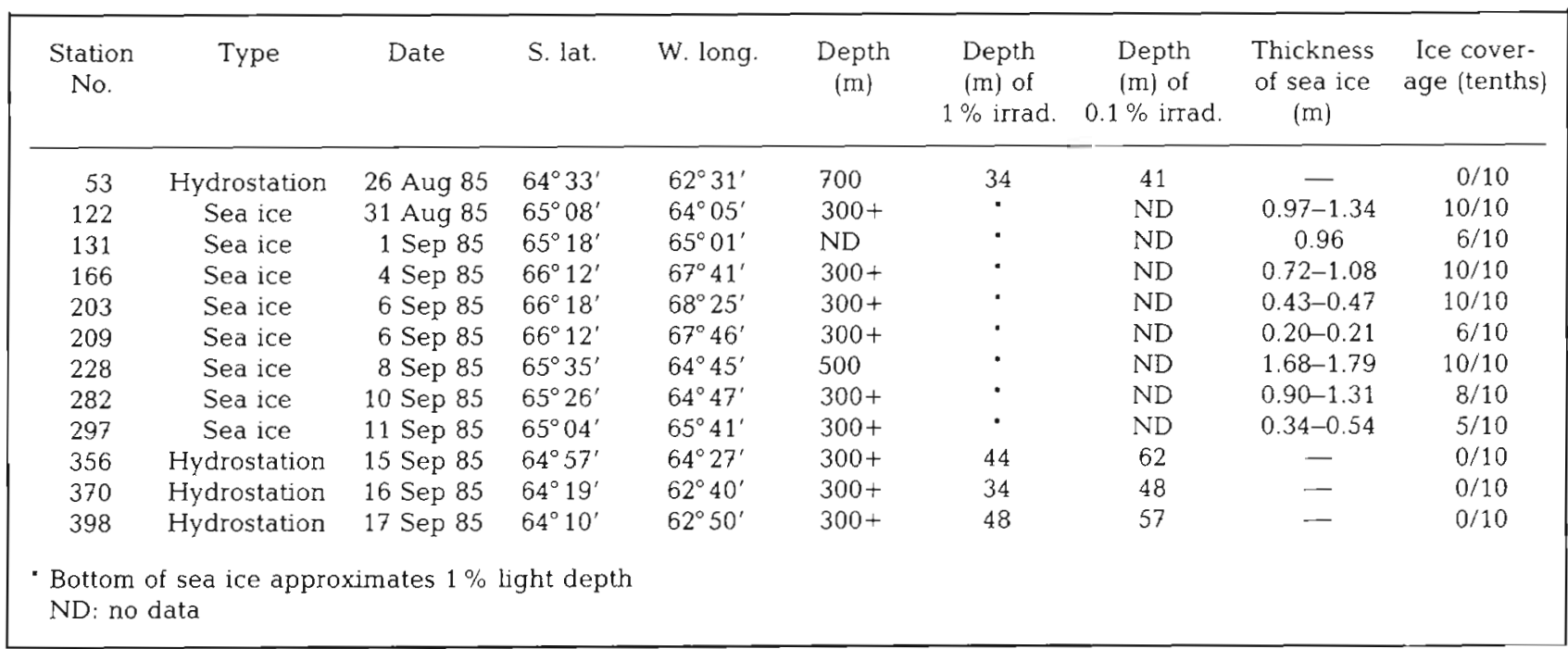


Fig. 1. Cruise track and stations on 1985 Wintercruise of R/V Polar Duke. (O) Hydrostations; (๑) sea ice stations

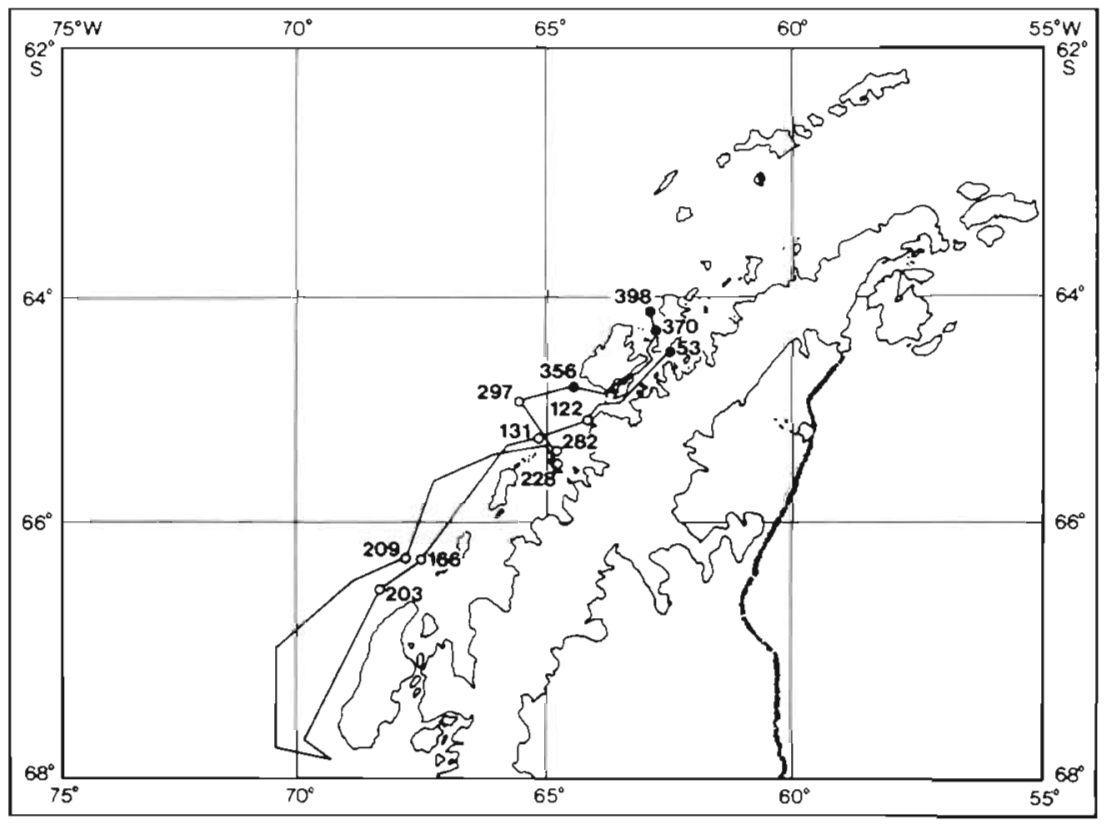

${ }^{14} \mathrm{CO}_{2}$ fixation of sea ice microalgae was determined by the technique of $\mathrm{Li}$ et al. (1980). Samples of sea ice microalgae were incubated for $24 \mathrm{~h}$ at $58 \mu$ Einsteins $\mathrm{m}^{-2} \mathrm{~s}^{-1}$ and $-1.9^{\circ} \mathrm{C}$ before being filtered onto $\mathrm{GF} / \mathrm{C}$ filters $(25 \mathrm{~mm}$ dia) as for primary production. Filters were frozen at $-20^{\circ} \mathrm{C}$ until extraction at USC. This crude fractionation yielded an aqueous methanol-soluble fraction (metabolites), a chloroform-soluble fraction (lipid), a hot $5 \%$ TCA-soluble fraction (polysaccharide), and a hot $5 \%$ TCA-insoluble fraction (protein). The amount of ${ }^{14} \mathrm{C}$ incorporated into these fractions was radioassayed as described above.

Rates of bacterial production were measured in $150 \mathrm{ml}$ serum bottles (Wheaton) according to the procedure of Fuhrman \& Azam (1980) as modified by Kottmeier et al. (1987). [Methyl- ${ }^{3} \mathrm{H}$ ]-thymidine (New England Nuclear) (78 Ci mmol ${ }^{-1}$ sp. act.) was diluted to $16 \mathrm{Ci} \mathrm{mmol}{ }^{-1}$ with cold thymidine (Sigma) and added to each serum bottle to yield a final added concentration of $10.2 \mathrm{nM}$ thymidine. Serum bottles were incubated in the dark at $-1.9 \pm 0.1^{\circ} \mathrm{C}$ in Freezesafes. Bacterial production was measured by incorporation of ${ }^{3} \mathrm{H}$-thymidine into cold trichloroacetic acid (TCA) precipitable material collected on $0.2 \mu \mathrm{m}$ pore size Nuclepore filters. Filters were rinsed 3 times with $5 \mathrm{ml}$ of cold $\left(0^{\circ} \mathrm{C}\right) 5 \%$ TCA following extraction with $5 \%$ TCA to rinse away excess ${ }^{3} \mathrm{H}$-thymidine not incorporated by bacteria. Filters were radioassayed at USC according to the procedure described above. Replicate determinations agreed within 10\%. Bacterial cell production was calculated from a conversion factor of $2.05 \times 10^{18}$ cells per mole of thymidine incorporated (Riemann et al. 1982). This yields a conservative estimate of bacterial cell production since the
The rate of synthesis of low molecular weight metabolites, lipids, polysaccharides, and protein, by 
conversion factor has been reported to range from 4 to $60 \times 10^{18}$ cells per mole of thymidine incorporated $(\mathrm{H}$. Ducklow pers. comm.). Using epifluorescence microscopy bacterial biovolumes were estimated from cell dimensions (Zimmerman 1977) of acridine orange stained samples (Hobbie et al. 1977). Bacterial biomass was derived from biovolume using a conversion factor

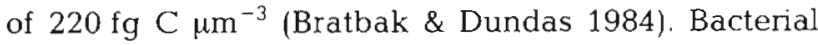
carbon production was determined from cell production and average cell biomass.

Daily primary production and bacterial production (carbon or cell) in sea ice were calculated by correcting for FSW dilution of the sample (Grossi et al. 1987) and then multiplied by the thickness of the sea ice.

Sections of sea ice were allowed to melt at $20^{\circ} \mathrm{C}$ prior to filtration onto $\mathrm{GF} / \mathrm{C}$ filters ( $47 \mathrm{~mm}$ dia) for determination of chlorophyll a and phaeopigments. Samples of the seawater or slurries of sea ice used in primary production experiments were also filtered. Filters were frozen at $-20^{\circ} \mathrm{C}$ until extraction. Filters were extracted in $100 \%$ acetone and analysed fluorometrically following the method of Strickland \& Parsons (1972).

\section{RESULTS}

Surface irradiance varied markedly during the cruise. Average daily irradiance was $158 \pm 21$ (SE) $\mu$ Einsteins $\mathrm{m}^{-2} \mathrm{~s}^{-1}$, with instantaneous midday irradiance as high as $1535 \mu$ Einsteins $\mathrm{m}^{-2} \mathrm{~s}^{-1}$ (Table 2). In ice-free waters, the depth to which $0.1 \%$ of surface irradiance penetrated ranged from 41 to $62 \mathrm{~m}$ (Table 1). Instantaneous downwelling irradiance on the surface of sea ice ranged from 140 to $826 \mu$ Einsteins $\mathrm{m}^{-2} \mathrm{~s}^{-1}$ (Table 2). Previous studies indicate a 60 to $90 \%$ albedo in polar regions (Palmisano et al. 1987). Downwelling irradiance was greatly attenuated directly beneath sea ice, ranging from 4 to $20 \mu$ Einsteins $\mathrm{m}^{-2} \mathrm{~s}^{-1}$, but was higher between ice cakes, ranging from 18 to $47 \mu$ Einsteins $\mathrm{m}^{-2} \mathrm{~s}^{-1}$. Thus the bottom of sea ice 0.2 to $1.8 \mathrm{~m}$ thick approximated the depth of $1 \%$ of surface irradiance, which was found at 34 to $48 \mathrm{~m}$ depth in ice-free waters.

Hydrostations were characterized by low concentrations of chlorophyll a ranging from 0.02 to $0.13 \mathrm{mg}$ $\mathrm{m}^{-3}$, almost evenly distributed down to the $0.1 \%$ light depth (Fig. 2A to D). Integrated to the $0.1 \%$ light depth chlorophyll a ranged from 1.19 to $5.53 \mathrm{mg} \mathrm{m}^{-2}$, with an average of $3.64 \pm 1.09$ (SE) $\mathrm{mg} \mathrm{m}^{-2}$ (Table 3). Sea ice exhibited considerably higher concentrations of chlorophyll $a$, ranging from 2.0 to $48.5 \mathrm{mg} \mathrm{m}^{-3}$ of meltwater (Fig. 3A to $\mathrm{H}$ ). Integrated over the ice thickness $(0.20$ to $1.79 \mathrm{~m}$ ) chlorophyll a ranged from 1.2 to $30 \mathrm{mg} \mathrm{m}^{-2}$. with an average of $9.4 \pm 1.9$ (SE) $\mathrm{mg} \mathrm{m}^{-2}$ (Table 4). In
Table 2. Summary of surface and sea ice irradiance measured from 25 Aug to 19 Sep 1985 on the 1985 Wintercruise. Units are $\mu$ Einsteins $\mathrm{m}^{-2} \mathrm{~s}^{-1}$

\begin{tabular}{|lcc|}
\hline Location & $\begin{array}{c}\text { Type of irradiance } \\
\text { measurement }\end{array}$ & $\begin{array}{c}\text { Mean and/or } \\
\text { range }\end{array}$ \\
\hline $\begin{array}{l}\text { Helicopter deck of } \\
\text { Polar Duke }\end{array}$ & Average daily & $\begin{array}{l}158 \pm 21 \text { (SE) } \\
(37-517) \\
140-1535\end{array}$ \\
$\begin{array}{l}\text { Hydrostation - } \\
100 \% \text { light depth }\end{array}$ & Instantaneous & $100-383$ \\
$\begin{array}{l}\text { Surface of sea ice } \\
\text { (corrected for }\end{array}$ & Instantaneous & $140-826$ \\
$\begin{array}{l}\text { albedo and } \\
\text { reflectance) }\end{array}$ & \\
$\begin{array}{l}\text { Bottom of sea ice } \\
\text { Between cakes of } \\
\text { sea ice }\end{array}$ & Instantaneous & $4-20$ \\
- $\begin{array}{l}\text { Represents } 24 \mathrm{~h} \text { integrated value divided by } 8.64 \times 10^{4} \mathrm{~s} \\
24 \mathrm{~h}^{-1}\end{array}$ & $18-47$ \\
\hline
\end{tabular}

seawater $3 \mathrm{~m}$ beneath sea ice, chlorophyll a was higher than in ice-free seawater; it ranged from 0.06 to $1.30 \mathrm{mg} \mathrm{m}^{-3}$, amounting to $1.2 \pm 1.1 \mathrm{mg} \mathrm{m}^{-2}$ for the integrated $3 \mathrm{~m}$ water column.

Distribution of phaeopigments at hydrostations paralleled that of chlorophyll $a$, but concentrations were lower ranging from 0.03 to $0.05 \mathrm{mg} \mathrm{m}^{-3}$ (Fig. $2 \mathrm{~A}$ to $\mathrm{D}$ ). Phaeopigments: chlorophyll a ratios averaged $0.48 \pm$ 0.04 (SE) and ranged from 0.28 to 0.82 , suggesting some breakdown and/or grazing of chlorophyll $a$ in the water column. Phaeopigments in sea ice and underlying seawater also paralleled the distribution of chlorophyll a concentrations (Fig. 3A to $\mathrm{H}$ ). They ranged from 1 to $14 \mathrm{mg} \mathrm{m}^{-3}$ for sea ice and 0.02 to 0.04 $\mathrm{mg} \mathrm{m}^{-3}$ for seawater. Phaeopigments: chlorophyll a ratios averaged $0.17 \pm 0.01(\mathrm{SE})$ and ranged from 0.03 to 0.53 for sea ice, suggesting little breakdown of chlorophyll a. In underlying seawater however, phaeopigments: chlorophyll a ratios averaged $0.35 \pm$ 0.13 (SE) and ranged from 0.14 to 0.64 , indicating more breakdown and/or grazing on chlorophyll a in seawater closely associated with sea ice.

Primary production at ice-free stations was greatest at the surface and decreased markedly down to the $0.1 \%$ light depth, paralleling the distribution of chlorophyl a (Fig. 4A to D). There was no measurable net carbon fixation at Stn 53 nor below $15 \mathrm{~m}$ at Stn 398, but other stations exhibited net carbon fixation down to the $0.1 \%$ light depth. Integrated to the $0.1 \%$ light depth, daily primary production was as high as 1101 $\mathrm{mg} \mathrm{C} \mathrm{m} \mathrm{m}^{-2} \mathrm{~d}^{-1}$, with an average of $288 \pm 313$ (SE) mg C $\mathrm{m}^{-2} \mathrm{~d}^{-1}$ (Table 3 ). Daily primary production in sea ice 
Fig. 2. Vertical profiles of chlorophyll a and phaeopigments from hydrostations

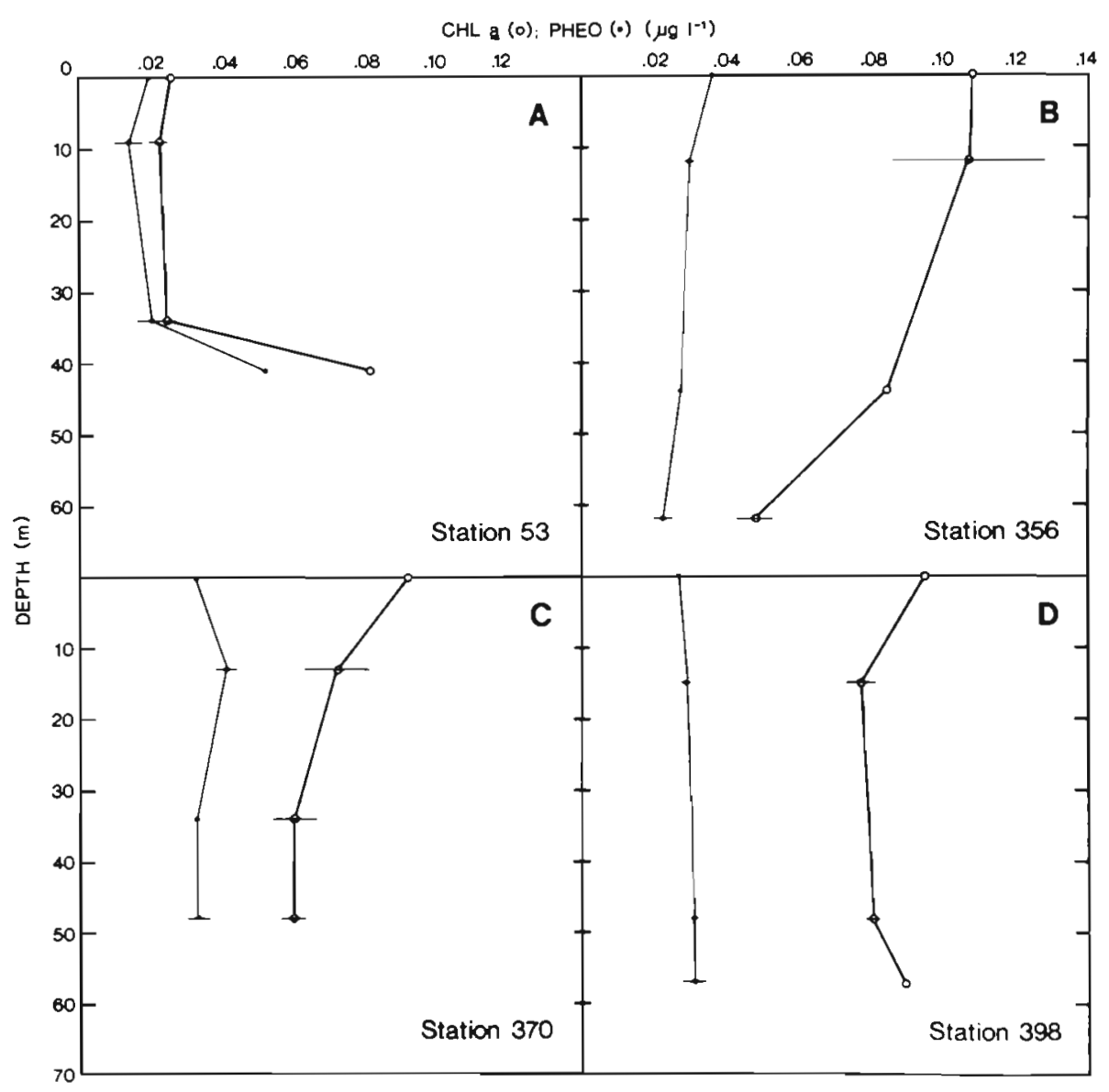

Table 3. Hydrostation chlorophyll a, primary production, bacterial carbon production, and bacterial cell production on the 1985 Wintercruise. All values integrated to the depth of $0.1 \%$ light. Average bacterial cell $=21.2 \mathrm{fg} \mathrm{C}$

\begin{tabular}{|c|c|c|c|c|c|}
\hline Station & $\begin{array}{c}\text { Depth of } \\
0.1 \% \text { light }(\mathrm{m})\end{array}$ & $\begin{array}{l}\text { Chlorophyll a } \\
\quad\left(\mathrm{mg} \mathrm{m}^{-2}\right)\end{array}$ & $\begin{array}{l}\text { Primary production } \\
\qquad\left(\mathrm{mg} \mathrm{C} \mathrm{m}^{-2} \mathrm{~d}^{-1}\right)\end{array}$ & $\begin{array}{l}\text { Bacterial carbon } \\
\text { production } \\
\left(\mathrm{mg} \mathrm{C} \mathrm{m}^{-2} \mathrm{~d}^{-1}\right)\end{array}$ & $\begin{array}{c}\text { Bacterial cell } \\
\text { production } \\
\left(10^{10} \text { cells } \mathrm{m}^{-2} \mathrm{~d}^{-1}\right)\end{array}$ \\
\hline 53 & 41 & 1.19 & NM & 16.8 & 79.2 \\
\hline 356 & 62 & 5.53 & 1101 & 10.7 & 50.6 \\
\hline 370 & 48 & 3.31 & 40 & 2.5 & 11.8 \\
\hline 398 & 57 & 4.64 & 11 & 19.1 & 90.1 \\
\hline$\overline{\mathrm{x}} \pm \mathrm{SE}$ & $52 \pm 5$ & $3.64 \pm 1.09$ & $288 \pm 313$ & $12.3 \pm 4.3$ & $57.9 \pm 20.2$ \\
\hline \multicolumn{6}{|c|}{ NM: not measurable } \\
\hline
\end{tabular}

ranged from no measurable net carbon fixation at Stn 122 to $60.0 \mathrm{mg} \mathrm{C} \mathrm{m} \mathrm{m}^{-2} \mathrm{~d}^{-1}$, with an average of $35.0 \pm$ $11.7 \mathrm{mg} \mathrm{C} \mathrm{m}^{-2} \mathrm{~d}^{-1}$ (Table 4 ). In seawater $3 \mathrm{~m}$ beneath sea ice, primary production ranged from 0.2 to $1.9 \mathrm{mg}$ $\mathrm{C} \mathrm{m} \mathrm{m}^{-2} \mathrm{~d}^{-1}$, with an average of $0.8 \pm 0.5 \mathrm{mg} \mathrm{C} \mathrm{m}^{-2} \mathrm{~d}^{-1}$.

The majority of recently fixed carbon in sea ice was partitioned into protein (37 to $44 \%$ ) (Table 5) by an algal assemblage dominated in biomass by centric diatoms. Less was incorporated into polysaccharides (29 to $31 \%$ ), low molecular weight compounds (19 to $22 \%$ ), and lipids ( 7 to $11 \%$ ).
Bacterial cell and carbon production at ice-free stations generally exhibited distribution patterns inversely related to primary production (Fig. 4A to D). Except for Stn 53, peak cell and carbon production occurred at the $10 \%$ light depth, and varied from 0.4 to $2.6 \times 10^{10}$ cells $\mathrm{m}^{-3} \mathrm{~d}^{-1}$ and 0.1 to $0.5 \mathrm{mg} \mathrm{C} \mathrm{m}^{-3} \mathrm{~d}^{-1}$ respectively. Integrated to the $0.1 \%$ light depth, bacterial cell production averaged $57.9 \pm 20.2(\mathrm{SE}) \times 10^{10}$ cells $\mathrm{m}^{-2} \mathrm{~d}^{-1}$, while carbon production averaged 12.3 \pm 4.3 (SE) $\mathrm{mg} \mathrm{C} \mathrm{m}^{-2} \mathrm{~d}^{-1}$ (Table 3). In sea ice, bacterial cell production averaged $20.5 \pm 11.0(\mathrm{SE}) \times 10^{10}$ cells 




Fig. 3. Vertical profiles of chlorophyll $a$ and phaeopigments from cores of sea ice taken at ice stations. In seawater $3 \mathrm{~m}$ beneath the sea ice, chlorophyll a ranged from 0.06 to $1.30 \mathrm{mg} \mathrm{m}^{-3}$, while phaeopigments ranged from 0.02 to $0.28 \mathrm{mg} \mathrm{m}^{-3} \mathrm{Horizontal}$ bars represent the range found in duplicate cores

$\mathrm{m}^{-2} \mathrm{~d}^{-1}$, while carbon production averaged $5.2 \pm 2.8$ (SE) $\mathrm{mg} \mathrm{C} \mathrm{m}^{-2} \mathrm{~d}^{-1}$ (Table 4). Bacterial cell and carbon production in seawater $3 \mathrm{~m}$ beneath sea ice were lower than in sea ice, averaging $4.5 \pm 3.5(\mathrm{SE}) \times 10^{10}$ cells $\mathrm{m}^{-2} \mathrm{~d}^{-1}$ and $1.0 \pm 0.7 \mathrm{mg} \mathrm{C} \mathrm{m} \mathrm{m}^{-2} \mathrm{~d}^{-1}$ respectively.

Since the structural integrity of the sea ice was not maintained in productivity experiments as we have done for congelation and platelet ice (Grossi et al. 1987, Kottmeier et al. 1987) and only the bottom sections of ice were used, these results should be regarded as potential production for the ice. Unlike the congelation ice of McMurdo Sound (Gow et al. 1981), in which most of the microbial biomass accumulates in the bottom few $\mathrm{cm}$ of the ice (Sullivan \& Palmisano 1984, Grossi \& Sullivan 1985, Sullivan et al. 1985, Grossi et al. 1987, Kottmeier et al. 1987), cake ice on the Wintercruise exhibited significant microbial biomass throughout the ice column (Fig. 3), similar to pack ice (Ackley et al. 1979, Garrison \& Buck 1982, 1986). Since this ice has smaller horizontal $(<20 \mathrm{~m})$ and vertical dimensions (20 to $172 \mathrm{~cm}$ ) and is subjected to hydraulic pumping by wave action (S. Ackley pers. comm.), its microbial communities may be perfused more with seawater than land-fast sea ice. This may in part explain why high microbial biomass is distributed throughout the ice column. Ice meltwater slurries used for productivity experiments may thus reasonably reflect conditions which microbial communities experience in situ in cake ice, with salinities and nutrient concentrations close to that of the surrounding seawater. In addition, assimilation numbers ranged from 0.11 to $0.55 \mathrm{mg} \mathrm{C} \mathrm{mg} \mathrm{Chl} \mathrm{a}^{-1} \mathrm{~h}^{-1}$, which are comparable to the range of 0.17 to $1.95 \mathrm{mg} \mathrm{C} \mathrm{mg} \mathrm{Chl}$ $\mathrm{a}^{-1} \mathrm{~h}^{-1}$ found for intact congelation ice incubated in situ at McMurdo Sound (Grossi 1985, Grossi et al. 1987). This suggests minimal perturbations of ice algal metabolism during productivity experiments. Hence the present results may approach in situ rates of photosynthesis.

Spearman rank correlations were calculated for bacterial cell production, secondary production, microalgal biomass (chlorophyll a), breakdown and/or grazing of chlorophyll a (phaeopigments), and primary production for hydrostations and ice stations combined (Tate \& Clelland 1957). No significant correlations $(p<0.05)$ were found between bacterial carbon and cell produc- 
Table 4. Summary of ice station chlorophyll a (mean and range), primary production, bacterial carbon production, and bacterial cell production on the 1985 Wintercruise. SI: sea ice; SW: $3 \mathrm{~m}$ seawater beneath sea ice. Seawater values are integrated over $3 \mathrm{~m}$. Average seawater bacterial cell $=21.2 \mathrm{fg} \mathrm{C}$ and sea ice bacterial cell $=25.4 \mathrm{fg} \mathrm{C}$

\begin{tabular}{|c|c|c|c|c|c|}
\hline \multicolumn{2}{|c|}{ Station } & \multirow{2}{*}{$\frac{\begin{array}{c}\text { Chlorophyll a } \\
\left.\text { (mg m }^{-2}\right)\end{array}}{11.6}$} & \multirow{2}{*}{$\begin{array}{l}\begin{array}{l}\text { Primary production } \\
\left(\mathrm{mg} \mathrm{C} \mathrm{m}^{-2} \mathrm{~d}^{-1}\right)\end{array} \\
\mathrm{NM}\end{array}$} & \multirow{2}{*}{$\frac{\begin{array}{c}\text { Bacterial carbon production } \\
\left(\mathrm{mg} \mathrm{C} \mathrm{m}^{-2} \mathrm{~d}^{-1}\right)\end{array}}{8.5}$} & \multirow{2}{*}{$\begin{array}{c}\begin{array}{c}\text { Bacterial cell production } \\
\left(10^{10} \text { cells } \mathrm{m}^{-2} \mathrm{~d}^{-1}\right)\end{array} \\
33.4\end{array}$} \\
\hline 122 & SI & & & & \\
\hline & SW & 0.2 & 0.3 & 0.9 & 4.4 \\
\hline 131 & SI & 5.5 & 60.0 & 13.4 & 52.7 \\
\hline & SW & 0.2 & 0.2 & 2.8 & 13.0 \\
\hline 166 & SI & $\begin{array}{c}12.8 \\
(11.5-14.1)\end{array}$ & 48.7 & 1.9 & 7.4 \\
\hline \multirow[t]{2}{*}{203} & SI & $\begin{array}{c}4.2 \\
(3.2-5.1)\end{array}$ & ND & ND & ND \\
\hline & SW & 0.4 & 0.7 & 0.1 & 0.5 \\
\hline 209 & SI & $\begin{array}{c}2.0 \\
(1.2-2.8)\end{array}$ & 24.7 & 0.1 & 0.3 \\
\hline 228 & SI & $\begin{array}{c}23.0 \\
(15.9-30.0)\end{array}$ & ND & ND & ND \\
\hline 282 & SI & $\begin{array}{c}8.4 \\
(5.9-10.9)\end{array}$ & ND & ND & ND \\
\hline 297 & SI & $\begin{array}{c}5.8 \\
(4.5-7.2)\end{array}$ & 41.8 & 2.2 & 8.6 \\
\hline & SW & 3.9 & 1.9 & NM & NM \\
\hline \multirow{2}{*}{\multicolumn{2}{|c|}{$\begin{array}{l}S I \bar{x} \pm S E \\
S W \bar{x} \pm S E\end{array}$}} & $9.4 \pm 1.9$ & $35.0 \pm 11.7$ & $5.2 \pm 2.8$ & $20.5 \pm 11.0$ \\
\hline & & $1.2 \pm 1.1$ & $0.8 \pm 0.5$ & $1.0 \pm 0.7$ & $4.5 \pm 3.5$ \\
\hline
\end{tabular}

tion and either chlorophyll a or primary production. This contrasts sharply with positive correlations found by others (Hobbie \& Rublee 1977. Azam et al. 1983, Grossi et al. 1984, Kottmeier et al. 1987).

\section{DISCUSSION}

During late winter considerable microbial biomass and production were associated with sea ice west of the Antarctic Peninsula. Most of the chlorophyll a, phaeopigments, primary production, and bacterial production was observed within sea ice up to $1.79 \mathrm{~m}$ thick, and was equal to that found in several meters of underlying seawater (Table 6). We hypothesize that sea ice initiates and maintains relatively high levels of primary production and bacterial production in the Southern Ocean at these latitudes in late winter, a season formerly thought to be totally unproductive due to low irradiance.

Although surface irradiance varied markedly during this time of year, downwelling irradiance was adequate for net photosynthesis near the surface in icefree water and in sea ice. At ice-free stations, surface downwelling irradiance just exceeded the 200 to 500 $\mu$ Einsteins $\mathrm{m}^{-2} \mathrm{~s}^{-1}$ apparently required to saturate photosynthesis at least for summer populations of
Antarctic phytoplankton (Sakshaug \& Holm-Hansen 1986). Irradiance may have been sufficient to exceed saturation for photosynthesis of phytoplankton down to approximately the $50 \%$ light depth, suggesting why primary production was greatest at the surface of the water column. Photosynthesis by ice microalgae, known to saturate from 5 to $21 \mu$ Einsteins $\mathrm{m}^{-2} \mathrm{~s}^{-1}$ (Bunt 1964, Palmisano et al. 1985, Horner 1985), was also saturated by downwelling irradiance at the surface and within the sea ice matrix. This was particularly true between ice cakes where slurries of ice algae were blooming at higher irradiances than those found beneath the ice, which may be as low as $1 \%$ of surface irradiance. Phytoplankton beneath a heavy concentration of sea ice may not be exposed to irradiance saturating for photosynthesis and may not exhibit net photosynthesis and growth (Sullivan et al. 1984, 1985). This may account in part for the low chlorophyll a concentrations seen in the seawater.

In this drifting cake ice we found a high percent incorporation of photosynthetically fixed carbon into protein by ice microalgae in contrast to our studies of the austral summer bloom in congelation ice of McMurdo Sound (Palmisano \& Sullivan 1985). We interpret these data to indicate that ice microalgae sampled during the Wintercruise were not nutrient limited and were experiencing net growth. Incorpora- 


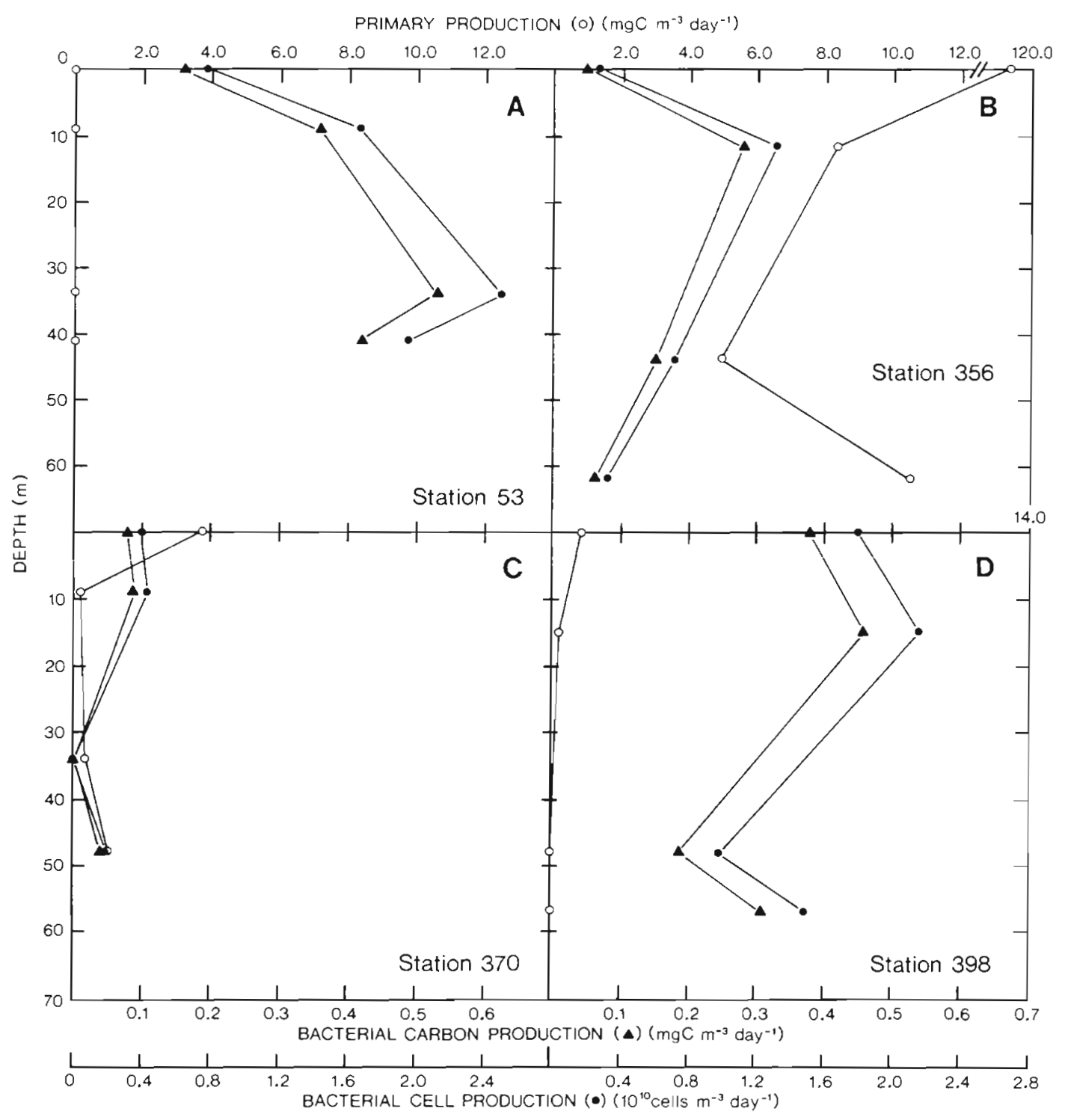

Fig. 4. Vertical profiles of primary production, bacterial carbon production, and bacterial cell production from hydrostations

Table 5. Partitioning of fixed ${ }^{14} \mathrm{C}$-carbon by sea ice microalgae from the 1985 Wintercruise

\begin{tabular}{|lcc|}
\hline Fraction & \multicolumn{2}{c|}{$\%$ of total } \\
& Stn 209 & Stn 297 \\
\hline Protein & 37 & 44 \\
Polysaccharide & 29 & 31 \\
Small MW compounds & 22 & 19 \\
Lipid & 11 & 7 \\
\hline
\end{tabular}

tion of a large fraction of fixed carbon into proteins may reflect a 'shift-up' in algal growth rate (sensu Kjeldgaard et al. 1958), with increased rates of protein synthesis, as a bloom begins during late winter.

Thus at the surface in ice-free water and in sea ice, net production was supported by low but adequate irradiance. Integrated primary production at hydrostations down to 41 to $62 \mathrm{~m}$ was greater than mean summer Antarctic primary production (Nov to Feb) of $134 \mathrm{mg} \mathrm{C} \mathrm{m}^{-2} \mathrm{~d}^{-1}$ (El-Sayed 1984). In addition primary production in sea ice less than $2 \mathrm{~m}$ thick was approximately $25 \%$ of mean summer primary production. Also bacterial production may provide an important source of carbon to upper trophic levels via the microbial loop (Garrison et al. 1986, Kottmeler et al. 1987), since it was a substantial fraction of primary production at some stations (Tables 3,4 \& 6).

Estimates of annual primary production in the Southern Ocean therefore need to be revised to reflect this late-winter microbial productivity. Our results suggest that far from being a season of no production, which 
Table 6. Range of chlorophyll $a$, phaeopigments, primary production, bacterial carbon production, and bacterial cell production for hydrostations and ice stations (ice and $3 \mathrm{~m}$ seawater beneath sea ice) on the 1985 Wintercruise

\begin{tabular}{|c|c|c|c|}
\hline & \multirow[b]{2}{*}{ Hydrostation } & \multicolumn{2}{|c|}{ Ice station } \\
\hline & & Ice & 3 m seawater \\
\hline Chlorophyll $a\left(\mathrm{mg} \mathrm{m}^{-3}\right)$ & $0.02-0.11$ & $2.0-48.5$ & $0.1-4.3$ \\
\hline Phaeopigments ( $\mathrm{mg} \mathrm{m}^{-3}$ ) & $0.02-0.05$ & $1-14$ & $0.02-0.8$ \\
\hline Primary production $\left(\mathrm{mg} \mathrm{C} \mathrm{m} \mathrm{m}^{-3} \mathrm{~d}^{-1}\right.$ ) & NM-116 & $N M-124$ & $2.2-15.1$ \\
\hline Bacterial carbon production ( $\mathrm{mg} \mathrm{C} \mathrm{m}^{-3} \mathrm{~d}^{-1}$ ) & $0.1-0.6$ & $0.4-13.9$ & NM-0.9 \\
\hline Bacterial cell production $\left(10^{10}\right.$ cells $\left.\mathrm{m}^{-3} \mathrm{~d}^{-1}\right)$ & $0.4-2.6$ & $1.5-54.9$ & $N M-4.3$ \\
\hline
\end{tabular}

some have represented in their budgets of annual production (El-Sayed 1978, Smith \& Nelson 1986), substantial net primary production and bacterial production occur both in sea ice and in the water column. It is difficult however to assess how widespread this productivity is for the Southern Ocean. High productivity has been found in the water during summer for this region of the Antarctic Peninsula, while open ocean production has been more typical of oligotrophic regions (El-Sayed 1984). Assuming a productive area of water south of the Antarctic Convergence of $6 \times 10^{6}$ $\mathrm{km}^{2}$ (Holm-Hansen \& Huntley 1984) and an average water productivity of $0.288 \mathrm{~g} \mathrm{~m}^{-2} \mathrm{~d}^{-1}$ measured during the Wintercruise, yields $52 \times 10^{12} \mathrm{gm} \mathrm{C}$ for the month of September (negligible production assumed for phytoplankton in the water column beneath sea ice). Our observation of substantial blooms of ice algae as far south as $67^{\circ} 45.5^{\prime} \mathrm{S}$ in early September on the Wintercruise of the R/V Polar Duke, the recent observations of blooms of ice algae along the prime meridian during July-August on the Wintercruise of the R/V Polarstern (J. C. Comiso pers. comm.), and reports of ice algal growth for Arthur Harbor in July and August (Krebs 1983), coupled with measurements of net production at the very high latitude of McMurdo Sound in September (Kottmeier \& Sullivan unpubl. obs.), suggest that net production occurs in sea ice over a vast area in winter. Assuming 33 to $100 \%$ of Antarctic sea ice during September is productive (5.7 to $17.4 \times 10^{6} \mathrm{~km}^{2}$ from Zwally et al. 1983) and an average primary production of sea ice of $0.035 \mathrm{~g} \mathrm{C} \mathrm{m}^{-2} \mathrm{~d}^{-1}$ measured during the Wintercruise, yields 6 to $18 \times 10^{12} \mathrm{~g} \mathrm{C}$. Combined primary production for September would

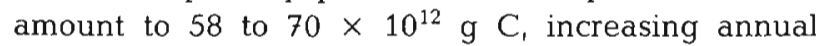
production 9 to $11 \%$ above the $610 \times 10^{12} \mathrm{~g} C$ estimated by El-Sayed (1978) for the Southern Ocean. Due to observed ice algal blooms during July and August, it is not fanciful to extend winter sea ice production back to the beginning of August, which would add another $3 \%$ to the estimate of annual primary production.
Assuming production for October at least equal to that for September (58 to $70 \times 10^{12} \mathrm{gm} \mathrm{C}$ ) would add another 9 to $11 \%$ to the estimate of annual production. Thus late winter production from August through October may contribute as much as $25 \%$ more production than estimated previously.

In addition to the quantity of winter production, a most important contribution to food web relationships may be the timing of the production. Late winter production may serve as an especially important source of food for grazers such as krill. Since concentrations of phytoplankton are generally believed to be too low and krill lipid reserves too slight to last more than a few weeks (Mauchline \& Fisher 1969), several hypotheses have been proposed to account for winter survival of krill. These include feeding on lipid-rich copepods (Boyd et al. 1984), use of their exoskeleton as a source of energy (Ikeda \& Dixon 1982), and grazing on sea ice algae (Hamner et al. 1983, Holm-Hansen \& Huntley 1984, Boyd et al. 1984, Garrison et al. 1986, Stretch et al. unpubl.). Sea ice in particular provides several habitats where active and concentrated assemblages of microalgae and bacteria are available for assimilation by krill. Recent evidence indicates that krill have high levels of digestive enzymes in late winter when the most probable source of food would be sea ice microbial communities (Garrison et al. 1986). In addition, phaeopigments : chlorophyll a ratios from the Wintercruise suggest that more chlorophyl $a$ breakdown and/or grazing occurs in seawater than in sea ice. This would be true if there were grazing on ice microalgae and faecal pellets were released into the underlying seawater. If the calculations of Ross \& Quetin (1986) are accurate in predicting concentrations of chlorophyll a required for reproduction of Euphasia superba ( 1 to $5 \mathrm{mg} \mathrm{m}^{-3}$ ), then krill could obtain sufficient carbon to prepare for reproduction by feeding on microalgae in late winter sea ice, but probably not on phytoplankton in seawater. Such hypothesized behavior may explain positive growth 
(Stepnik 1982) and ovarian development (Mauchline \& Fisher 1969) seen in krill during August and September. Late winter sea ice may therefore be an important feeding site for adult krill preparing to reproduce, long before the advent of phytoplankton blooms in icefree waters during the austral summer (Mauchline \& Fisher 1969, Makarov 1979, Ross \& Quetin 1986).

Sea ice during winter may also serve as an important nursery ground for larval krill. During the Wintercruise, swarms of larval krill were observed by our divers to be associated with and apparently grazing on blooms of ice algae as evidenced by the presence of green pigmented material in their foreguts. Ctenophores in turn were observed preying on larval krill swimming in seawater immediately underlying the sea ice. Sea ice may thus provide larval krill with not only an unexpected source of food from ice algae and bacteria (via the microbial loop), but also a refugium, analogous to that observed for some arctic amphipods (Carey 1985) and antarctic amphipods (Richardson \& Whitaker 1979, Kottmeier et al. 1984, 1985).

This study expands our knowledge of production in the Southern Ocean to late winter when little is known. Low irradiance at this time does not eliminate primary production as initially hypothesized; net primary production and bacterial production occur in sea ice and near the surface of ice-free water. In addition, a short food chain was associated with sea ice, consisting of krill and ctenophores at the higher trophic levels apparently supported in part by the production of ice microalgae and possibly bacteria. Early productivity in this thin layer of sea ice and at the surface of ice-free water apparently signals the beginning of a wave of productivity that spreads in the water column and along marginal ice edge zones as sea ice melts during the austral spring and summer.

Acknowledgements. The authors thank Dr. R. Moe and Mr. Todd Roberts for expert field assistance and scuba diving; Chief Scientist Dr. L. Quetin, Captain Mueller, and the crew of the R/V Polar Duke for assistance in making the cruise a success; Mr. B. Carter and ITT, Antarctic Services, Inc. for logistical support; Mr. Michael Lizotte for analysis of samples taken for carbon assimilation; Ms Laura Noskey for analysis of chlorophyll $a$ and phaeopigments, and 3 anonymous reviewers for critically reviewing the manuscript. This study was supported by National Science Foundation grant DPP8444783 to C. W. S.

\section{LITERATURE CITED}

Ackley, S. F., Buck, K. R., Taguchi, S. (1979). Standing crop of algae in the sea ice of the Weddel Sea region. Deep Sea Res. 26: 269-282

Azam, F., Fenchel, T., Field, J. G., Gray, J. S., Meyer-Reil, L. A., Thingstad, F. (1983). The ecological role of water- column microbes in the sea. Mar. Ecol. Prog. Ser. 10 $257-263$

Bodungen, B. von, Tilzer, M. M., Zeitzschel, B. (1982). Phytoplankton growth dynamics during spring blooms in Antarctic waters. Joint Oceanographic Assembly, 2-13 August 1982, Halifax, Canada. Abstracts of Invited Papers, p. 59

Boyd, C. M., Heyraud, M., Boyd, C. N. (1984). Feeding of the Antarctic krill Euphausia superba. J. Crustacean Biol. 4(1): $123-141$

Bratbak, G., Dundas, I. (1984). Bacterial dry matter content and biomass estimations. Appl. enviran. Microbiol. 48 $755-757$

Bunt, J. S. (1963). Diatoms of Antarctic sea ice as agents of primary production. Nature, Lond. 14: 197-200

Bunt, J. S. (1964). Primary productivity under sea ice in Antarctic waters. 2. Influence of light and other factors on photosynthetic activities of Antarctic marine microalgae. Antarct. Res. Ser 1: 27-31

Carey, A. G. (1985). Marine ice fauna: Arctic. In: Horner, R. A (ed.) Sea ice biota. CRC Press, Boca Raton, Florida, p. $173-190$

Clarke, D. B., Ackiley, S. F. (1984). Sea ice structure and biological activity in the Antarctic marginal ice zone. J. geophys. Res. 89: 2087-2095

El-Sayed, S. Z. (1967). On the productivity of the southwest Atlantic Ocean and the waters west of the Antarctic Peninsula. In: Schmitt, W., Llano, G. (ed.) Biology of Antarctic seas. II. American Geophysical Union, Washington, D.C., Antarct. Res. Ser. 11: 15-47

El-Sayed, S. Z. (1971). Observations on phytoplankton bloom in the Weddell Sea. In: Llano, G. A., Wallen, I. E. (ed.) Biology of Antarctic seas. IV. American Geophysical Union, Washington, D.C., Antarct. Res. Ser. 17: 301-312

El-Sayed, S. Z. (1978). Primary productivity and estimates of potential yields of the southern ocean. In: McWhinnie, $M$. A. (ed.) Polar research: to the present, and the future. Westview Press, Boulder, Colorado, p. 141-160

El-Sayed, S. Z. (1984). Productivity of the Antarctic waters - a reappraisal. In: Holm-Hansen, O., Bolis, L., Gilles, R. (ed.) Marine phytoplankton and productivity. Springer-Verlag, Berlin, p. 19-34

El-Sayed, S. Z., Taguchi, S. (1981). Primary production and standing crop of phytoplankton along the ice-edge in the Weddel Sea. Deep Sea Res. 28: 1017-1032

El-Sayed, S. Z., Weber, L. H. (1982). Spatial and temporal variations in phytoplanktgon biomass and primary productivity in the southwest Atlantic and the Scotia Sea. Polar Biol. 1: 83-90

El-Sayed, S. Z., Tumer, J. T. (1977). Productivity of the Antarctic and tropical subtropical regions: a comparative study. In - Dunbar, M. J. (ed.) Proceedings of SCOR/SCAR polar oceans conference, Montreal, Canada, May, 1974. Arctic Institute of North America, Calgary, Canada, p. 463-504

Fuhrman, J. A., Azam, F. (1980). Bacterioplankton secondary production estimates for coastal waters of British Columbia, Antarctica, and California. Appl. environ. Microbiol. 39: 1085-1095

Garrison, D. L., Buck, K. R. (1982). Sea-ice algae in the Weddell Sea. I. Biomass distribution and the physical environment. EOS (Trans. Am. geophys. Un.) 63: 47

Garrison, D. L., Buck, K. R. (1986). Algal biomass in Antarctic pack ice. EOS (Trans. Am. geophys. Un.) 67: 1030

Garrison, D. L., Ackley, S. F., Buck, K. R. (1983). A physical mechanism for establishing algal populations in frazil ice. Nature, Lond. 306: 363-365 
Garrison, D. L., Ackley, S. F., Sullivan, C. W. (1986). Sea ice microbial communities in Antarctica. Bioscience 36 243-250

Gow, A. J., Weeks, W. F., Govoni, J. W., Ackley, S. F. (1981). Physical and structural characteristics of sea ice in McMurdo Sound. Antarct. J. U. S. 16: 94-95

Grossi, S. M. (1985). Response of a sea ice microalgal community to a gradient in under ice irradiance. Ph. D. dissertation, Univ. of Southern California, Los Angeles

Grossi, S. M., Sullivan, C. W. (1985). Sea ice microbial communities. $V$. The vertical zonation of diatoms in an Antarctic fast ice community. J. Phycol. 21: 401-409

Grossi, S. M., Kottmeier, S. T., Sullivan, C. W. (1984). Sea ice microbial communities. III. Seasonal abundance of microalgae and associated bacteria, McMurdo Sound, Antarctica. Microb. Ecol. 10: 231-242

Grossi, S. M., Kottmeier, S. T., Moe, R. L., Taylor, G. T., Sullivan, C. W. (1987). Sea ice microbial communities, VI. Growth and primary production in bottom ice under graded snow cover. Mar. Ecol. Prog. Ser. 35: 153-164

Hamner, W. M., Hamner, P. P., Strand, S. W., Gilmer, R. W. (1983). Behavior of Antarctic krill, Euphausia superba. chemoreception, feeding, schooling and molting. Science 220: $433-435$

Hart, T. J. (1934). On the phytoplankton of the southwest Atlantic and the Bellinghausen Sea. 'Discovery' Rep. 8: $1-268$

Heywood, R. B., Whitaker, T. M. (1984). The Antarctic marine flora. In: Laws, R. M. (ed.) Antarctic ecology, Gulf Publishing, Houston, p. 373-419

Hobbie, J. E., Rublee, P. (1977). Radioactive studies of heterotrophic bacteria in aquatic ecosystems. In: Cairns, J. (ed.) Aquatic microbial communities. Garyland Publ., New York, p. 441-476

Hobbie, J. E., Daley, R. J., Jasper, S. (1977). Use of Nuclepore filters for counting bacteria by fluorescence microscopy. Appl. environ. Microbiol. 33: 1225-1228

Holm-Hansen, O., El-Sayed, S. Z., Franceschini, G. A., Cuhel, R. L. (1977). Primary production and the factors controlling phytoplankton growth in the Southern Ocean. In: Llano, G. A. (ed.) Adaptations within Antarctic ecosystems. Smithsonian Institution, Washington, D. C., p. 11-50

Holm-Hansen, O., Huntley, M. (1984). Feeding requirements of krill in relation to food sources. J. Crustacean Biol. 4(1): 156-173

Horner, R. A. (1985). Ecology of sea ice microalgae. In Horner, R. A. (ed.) Sea ice biota. CRC Press, Boca Raton, Florida, p. 83-103

Hoshiai, T. (1977). Seasonal change of ice communities in the sea ice near Syowa Station, Antarctica. In: Dunbar, M. J. (ed.) Polar oceans. Arctic Institute of North America, Calgary, Canada, p. 307-317

Hoshiai, T. (1981). Proliferation of ice algae in Syowa Station area, Antarctica. Mem. Nat. Inst. Polar Res. 35: 1-12

Ikeda, T., Dixon, P. (1982). Body shrinkage as a possible overwintering mechanism of the Antarctic krill, Euphausia superba Dana. J. exp. mar. Biol. Ecol. 62: 143-151

Jacques, G. (1983). Some ecophysiological aspects of the Antarctic phytoplankton. Polar Biol, 2: 27-33

Kjeldgaard, N. O., Maaloe, O., Schaechter, M. (1958). The transition between different physiological states during balanced growth of Salmonella typhimurium. J. gen. Microbiol. 19: 607-616

Kottmeier, S. T., Muscat, A. M., Craft, L. L., Kastendiek. J. E., Sullivan, C. W. (1984). Ecology of sea-ice microbial communities in McMurdo Sound, Antarctica in 1983. Antarct J. U. S. 19: 129-131
Kottmeier, S. T., Miller, M. A., Lizotte, M. P., Craft, L. L., Gulliksen, B., Sullivan, C. W. (1985). Ecology of sea ice microbial communities (SIMCO) during the 1984 winter to summer transition in McMurdo Sound, Antarctica. Antarct. J. U. S. 20: 128-130

Kottmeier, S. T., Grossi, S. McG., Sullivan, C. W. (1987). Sea ice microbial communities. VIII. Bacterial production in annual sea ice of McMurdo Sound, Antarctica. Mar. Ecol. Prog. Ser. 35: 175-186

Krebs, W. N. (1983). Ecology of neritic marine diatoms, Arthur Harbor, Antarctica. Micropaleontology 29: 267-297

Li, W. K. W., Glover, H. E., Morris, I. (1980). Physiology of carbon photoassimilation by Oscillatoria thiebautii in the Caribbean Sea. Limnol. Oceanogr. 25: 447-456

Makarov, R. R. (1979). Spawning periods of antarctic euphausiids. Sov. J. mar. Biol. 5: 184-192

Mandelli, E. F., Burkholder, P. R. (1966). Primary productivity in the Gerlache and Bransfield Straits of Antarctica. J. mar. Res. 24: 15-27

Mauchline, J., Fisher, L. R. (1969). The biology of euphausiids. Academic Press, New York

McConville, M. J., Wetherbee, R. (1983). The bottom icè microalgal community from annual ice in the inshore waters of East Antarctica. J. Phycol. 19: 431-439

McConville, M. J., Mitchell, C., Wetherbee, R. (1985). Patterns of carbon assimilation in a microalgal community from annual sea ice, East Antarctica. Polar Biol. 4: 135-141

Nelson, D. M., Gordon, L. I. (1982). Production and pelagic dissolution of biogenic silica in the southern ocean. Geochim. cosmochim. Acta 46: 491-501

Palmisano, A. C., Sullivan, C. W. (1983). Sea ice microbial communities (SIMCO). I. Distribution, abundance, and primary production of ice microalgae in McMurdo Sound, Antarctica in 1980. Polar Biol. 2: 171-177

Palmisano, A. C., Sullivan, C. W. (1985). Physiological response of microalgae in the ice-platelet layer to ambient low-light conditions. In: Siegfried, R., Condy, P. R., Laws, R. M. (ed.) Antarctic nutrient cycles and food webs. Springer-Verlag, Berlin, p. 84-103

Palmisano, A. C., SooHoo, J. B., Sullivan, C. W. (1985). Photosynthesis-irradiance relationships in sea ice microalgae from McMurdo Sound, Antarctica. J. Phycol. 21: 341-346

Palmisano, A. C., SooHoo, J. B., Moe, R. L., Sullivan, C. W. (1987). Sea ice microbial communities. VII. Changes in under-ice spectral irradiance during the development of Antarctic sea ice microalgal communities. Mar. Ecol. Prog. Ser. 35: 165-173

Richardson, M. G., Whitaker, T. M. (1979). An Antarctic fastice food chain: observations on the interaction of the amphipod Pontogeneia antarctica Chevreux with iceassociated micro-algae. Br. Antarct. Surv. Bull. 47: $107-115$

Riemann, B., Fuhrman, J., Azam, F. (1982). Bacterial, secondary production in freshwater measured by ${ }^{3} \mathrm{H}$-thymidine incorporation method. Microb. Ecol. 8: 101-114

Ross, R. M., Quetin, L. B. (1986). How productive are Antarctic krill? Bioscience 36: 264-269

Sakshaug, E., Holm-Hansen, O. (1986). Photoadaptation in Antarctic phytoplankton: variations in growth rate, chemical composition and P versus I curves. J. Plankton Res. 8: 459-473

Smith, W. O., Nelson, D. M. (1985). Phytoplankton bloom produced by a receding ice edge in the Ross Sea: spatial coherence with the density field. Science 227: 163-166

Smith, W. O., Nelson, D. M. (1986). Importance of ice edge phytoplankton production in the southern ocean. Bioscience 36: 251-257 
Stepnik, R. (1982). All-year populational studies of Euphausiacae (Crustacea) in the Admiralty Bay (King George Island, South Shetland Islands, Antarctica). Pol. Polar Res. 3: 49-68

Strickland, J. D. H., Parsons, T. R. (1972). A practical handbook of seawater analysis. 2nd edn. Bull. Fish Res. Bd Can. 167

Stringer, W. J., Barnett, D. G., Godin, R. H. (1984). Handbook for sea ice analysis and forecasting. Naval Environmental Prediction Research Facility, Monterey, California

Sullivan, C. W., Palmisano, A. C. (1984). Sea ice microbial communities: distribution, abundance, and diversity of ice bacteria in McMurdo Sound, Antarctica in 1980. Appl. environ. Microbiol. 47: 788-795

Sullivan, C. W., Palmisano, A. C., SooHoo, J. B. (1984). Influence of sea ice and sea ice biota on downwelling irradiance and spectral composition of light in McMurdo Sound. In: Blizard, M. A. (ed.) Ocean optics VII. Proc. SPIE (International Society for Optical Engineering, Bellingham, Washington) 489 , p. 159-165

Sullivan, C. W., Palmisano, A. C., Kottmeier, S. I., Grossi, S. M., Moe, R. L. (1985). The influence of light on growth and development of the sea-ice microbial community of McMurdo Sound. In: Siegfried, R., Condy, P, R., Laws, R. $M$. (ed.) Antarctic nutrient cycles and food webs. SpringerVerlag, Berlin, p. 78-83

Talling, J. F. (1957). The phytoplankton population as a compound photosynthetic system. New Phytol. 56: 133-149

Tate, W. M. Clelland, R. C. (1957). Nonparametric and shortcut statistics. Interstate Printers and Publishers, Inc., Danville, Illinois

Whitaker, T. M. (1977). Sea ice habitats of Signy Island (South Orkneys) and their primary productivity. In: Llano, G. A. (ed.) Adaptations within Antarctic ecosystems. Gulf Publ. Co., Houston, Texas, p. 75-82

Zimmermann, R. (1977). Estimations of bacterial number and biomass by epifluorescence microscopy and scanning electron microscopy. In: Rheinheimer, G. (ed.) Microbial ecology of brackish water environment. Springer-Verlag, New York, p. 103-120

Zwally, H. J., Parkinson, C. L., Comiso, J. C. (1983). Variability of Antarctic sea ice and changes in carbon dioxide. Science 220: 1005-1012

This article was submitted to the editor; it was accepted for printing on January 15,1987 